\title{
CONSTRUCTING A COURSE ON INDONESIAN SHADOW PUPPETS FOR INTERNATIONAL STUDENTS
}

\author{
Yosep Bambang Margono Slamet \\ yosepbbmargono@gmail.com \\ English Department, Akademi Bahasa Asing 17, Semarang
}

\begin{abstract}
This paper is a course design on Indonesian shadow puppet to promote Indonesian culture to international students as a way of building a cultural bridge to create global citizens. In today's world, it is of paramount importance for every individual from diverse cultural, linguistic, and ethnic backgrounds to understand each other and work together. Creating this course is to introduce and promote an aspect Indonesian culture so that international students are more interested in and knowledgeable of Indonesian people and culture in general. Even though-students only learn an aspect of Indonesian culture it is expected that they will be able to explore Indonesian culture in a broad sense.
\end{abstract}

Key words: Indonesian culture, cultural bridge, global citizens

Abstrak: Paper ini merupakan rancangan mata kuliah tentang wayang kulit Indonesia untuk mempromosikan kebudayaan Indonesia kepada mahasiswa internasional sebagai upaya untuk membangun jembatan budaya untuk menciptakan warganegara dunia. Dewasa ini sangat penting bagi kita semua untuk saling memahami dan bekerja sama, sekalipun kita memiliki latar belakang budaya, bahasa, dan etnis yang berbeda. Merancang mata kuliah ini berarti memperkenalkan dan mempromosikan satu aspek dari kebudayaan Indonesia sehingga mahasiswa internasional lebih tertarik pada dan lebih memahami manusia dan kebudayaan Indonesia secara umum. Meskipun hanya mempelajari satu aspek dari kebudayaan Indonesia, diharapkan mahasiswa internasional bisa mengeksplorasi kebudayaan Indonesia dalam arti luas dari mata kuliah ini.

Kata kunci: kebudayaan Indonesia, jembatan budaya, warganegara dunia 


\section{INTRODUCTION}

I was a student at the University of Iowa and wanted to promote Indonesian culture to American and international students. The chance to do that came when the university offered me to teach the Indonesian language in 2006. This is a great experience because I met enthusiastic students from different countries like USA, India, and Korea. It is during the tutorial times that students and I talked about Indonesian people and culture, including wayang kulit or shadow puppets; and our talks were mostly in the Indonesian language. It is from my tutoring experiences that I learn that among tens of thousands of students in the university, there are some students who are really interested in Indonesia. For them, learning Indonesian language is just the beginning of knowing more about Indonesia.

On reflection, I have been thinking about the possibility for having other means of promoting Indonesian culture. I want Indonesia to become not only a kind of imagined community (Anderson, 1991) for American and international students, but a real one; and one of the ways to make Indonesia real for them is through a course other than on Indonesian language. However, the course should not only be academic in which students only read scholarly readings or theories, but one that also offers actual experience about one aspect of Indonesia. Thinking about this, I came to a decision that a course on Indonesian shadow puppets is a good choice. In this course, students will not only learn about Indonesian shadow puppets from scholarly readings, but will also have the chance to see and play with real puppets, recognize major characters, and watch videos of shadow puppet performances.

In other words, this course is a combination between theory and entertainment. Teaching about Indonesian shadow puppets to American and international students will be a very difficult job. On the other hand, giving out real puppets to students and watching videos on shadow puppet performances will be more experiential than academic. Therefore, I decided to choose to combine both academic and experiential approaches. This way, students will have sufficient academic information on Indonesian shadow puppets (and Indonesian people and culture in general) and at the same time they have real experience with Indonesian shadow puppets. 


\section{WHY I CONSTRUCTED THE COURSE THE WAY I DID}

As a course for upper undergraduate and graduate level, it is the combination of mini lectures and discussion. Traditionally, the shadow puppet stories are based on the Ramayana and Mahabharata epics. But nowadays, many puppeteers write their own plays. Traditionally, the dalang (puppeteer) performed shadow puppet plays based on the formal scripts written by Raden Ngabehi Ranggawarsita, the official author of Surakarta Kingdom, in Central Java, who lived between 1802 and 1874. It was said that there were about 177 lakon (plays) written and compiled by Raden Ngabehi Ranggawarsita (Pustaka Raja Purwa, n.d.). This kind of performance lasted for about nine hours (Brandon, 1970). In contrast, today's performances may not use the old scripts and can last only in one hour to one and a half hour (Sears, 1989). To attract young people, some young puppeteers created new characters such as Batman and Superman (Cohen, 2007). Wayang kulit or shadow puppets have been changing to adapt to the new era but the basic elements remain.

In class, students will want to read various texts about Indonesian shadow puppets and watch many short videos on shadow puppet performances. Every week, they have tô write a one page response to readings and or videos and have discussion in class. It is important for me as the instructor that I listen to every student's ideas and views because it is their ideas and views that are important. I will serve mostly as a facilitator and will speak up when necessary. But of course I will explain the background of every reading and video to give them ideas for discussion. In addition, students will also write a six-to-nine page midterm paper on the topics that have been discussed in class. For the final exam, they will write a twelve-tofifteen-page paper. In addition to the final paper, they will make an oral presentation to the class. I expect them to do extensive research on a single shadow puppet character for their final paper. In addition to scholarly readings, I encourage students to use a video or videos for their final projects. By constructing the course in this way, I expect that students will have in-depth knowledge about the cultural, political, and aesthetic aspects of Indonesian shadow puppets.

\section{MY TEACHING PHILOSOPHY}

My teaching philosophy draws on Cushner and Brennan's (2007) ideas who emphasize the importance of teachers as educator in preparing their 
students to become global citizens. To become global citizens means that they need to develop intercultural relations to be able to work together with people from around the globe. According to them, people around the globe are now striving to work together and whoever works together needs to "develop an understanding of and sensitivity to the views of others as well as a sense of connectedness that taps into common values and goals" (pp. 1-2). It is in this spirit that I created this course.

In creating this course, the major idea is, according to Cushner and Brennan, to build a bridge to global competence. Indeed, without a cultural bridge, global competence will be difficult to achieve. Fadiman (1998) gives an example of how American culture and Hmong culture collide in the case of a Hmong child who suffers from epilepsy. From the American doctors' perspective, Hmong people are ignorant of the modern medicine and on the other hand, from the Hmong perspective, American doctors are ignorant of their understanding of health and wellness. I believe that cultural understanding can be achieved if we are not ignorant of other cultures and if we are willing to learn about other cultures. In today's world, interactions among people from different cultures are unavoidable and thus learning about other cultures is a must. It is in this realm that we need to have global competence, starting from a willingness to learn about other cultures.

In this course, instead of teaching students about broad concepts of culture or in this case, the broad concepts of Indonesian culture, I teach Indonesian culture through shadow puppets, one aspect of Indonesian culture. Shadow puppets are a good start to attract students' interest in Indonesian culture. One may wonder how teaching shadow puppets can become a bridge to global competence. My argument is that if students are interested in shadow puppets, they will explore more information about them. They can learn more about shadow puppets and education, and shadow puppets as a traditional art, or shadow puppets in global context and many more aspects of shadow puppets. In exploring more about shadow puppets, they will definitely understand more about Indonesian culture. In the end, their knowledge about Indonesia will make it easier for them to communicate with Indonesian people. Thus, the big idea starts from small ones. Further, because shadow puppets do not only belong to Indonesia but also belong to other Southeast Asian countries, students who are interested in them can explore shadow puppets in other countries, too.

In this way, I want to give students new possibilities to explore. By exploring new possibilities offered by shadow puppets, students can expand 
their vision of the world. At the same time, they can develop their identities, from not knowing or knowing a little bit about other cultures to knowing much more about them. Thus, by teaching shadow puppets to international students, I position myself as a teacher who takes part actively in intercultural dialogues among American and international students. I believe that classrooms and learning can be a strong bridge to global competence and teachers have a pivotal role in building these bridges.

\section{THE TOPICS AND THEIR SEQUENCE}

Javanese shadow puppets reflect the Javanese lives or Javanese ways of life. The life cycle, from birth to death, is often described in a shadow puppet performance (Keeler, 1992). Therefore, creating a course on Javanese shadow puppets is, to some extent, like creating a course on Javanese ways of life. For instance, traditionally a Javanese should (or even must) know where he places himself in his society. This social order is reflected in shadow puppet performances (Anderson, 1996). On the other hand, lay persons and people in power may have different understanding about the same story because they have different perspectives and interests. These kinds of aspects of life created challenges for me in choosing topics: How do I choose which one is important to present and discuss? However, I attempted to cover a broad perspective that is sufficient for a beginning course in Javanese shadow puppets. I chose basic, general topics so that interested students can develop their interest on their own later on after taking this course. I categorize the week-to-week topics into three: first, shadow puppet stories (week 4, 5, and 8); second, shadow puppet performances (week 6, 7, 11, and 12); and third, shadow puppets and social and cultural issues (week 3, 9, 10, and 14).

The course starts with the introduction in week 1 . I lay out the fact that shadow puppets are common across Southeast Asian countries. It is important to discuss the cultural setting in this region to understand how shadow puppets in many countries are related and how they are different. However, the focus will be on Javanese shadow puppets. In this week I will also give out puppets to students so that they have real experiences of seeing, holding, or even playing Javanese shadow puppet characters, both from the Ramayana and Mahabharata.

In week 2, we move on to the topic "Indonesian shadow puppets." I will show to students that there are more than one shadow puppets in Indonesia. In addition to Javanese shadow puppets, there are also Balinese 
shadow puppets and Sundanese rod puppets (wayang golek). I will also explain to students that Indonesian shadow puppets in this course refer to Javanese shadow puppets only. The reason for this is because I am a Javanese. It should be born in mind, however, that this has nothing to do with a feeling of superiority. I just do not know Sundanese and Balinese language and shadow puppets, thus it is difficult for me to understand Sundanese and Balinese shadow puppets as well as my understanding of Javanese shadow puppets.

In week 3, the topic we discuss is "Shadow puppets, novel, and film: The case of The Year of Living Dangerously." This is a novel by Koch (1983 [1979]). The film version of the novel has the same title. My goal in discussing this topic in this week is to engage students to shadow puppets. The setting of the novel is Jakarta in 1965, when Indonesia was under Soekarno, the first president of Indonesia. In this novel, Koch not only tells us about political conflicts in Indonesia at the time but also cultural backgrounds of Indonesia in general and Java in particular. We will discuss how Koch uses shadow puppets to describe the political conflicts. In addition, he also gives us description about some major characters in the Mahabharata. Above all, the novel and the film are in English, therefore it will be relatively easy to attract American and international students' interest in shadow puppets.

The discussion of shadow puppet characters are important because students need to know first what the characters look like. From their appearances, we can expect what kind of characters each puppet reveals (Long, 1982), whether they belong to the Ramayana or Mahabharata. I allocate week 4 and 5 for this discussion. The discussion of major characters will be very helpful in understanding shadow puppet stories.

What I mean by shadow puppet stories (topic in weeks 4,5 , and 8 ) may be different from the original stories of the Ramayana and Mahabharata (because shadow puppet stories are about the characters, I also include the topics in week 4 and 5 into shadow puppet stories). Traditionally, there were fixed scripts of shadow puppet performances. These fixed scripts are what I call stories; meanwhile Brandon (1970) call them "plays" or lakon in Javanese. However, in modern times, many more puppeteers wrote shadow puppet stories to be performed and their scripts are somewhat loose or even very loose. Therefore the stories may be different from the Ramayana and Mahabharata even though almost all stories are based on the two epics. 
For the topic of shadow puppet performances, in particular we discuss the components of shadow puppet performances such as the dalang (puppeteer), the waranggana (singers), the niyaga (musicians), the kelir (screen), the blencong (lamp) and other components in week 6. This is important to give students an overview of the performance. In week 7 , in particular we will discuss the role of clown servants which appear in both the Ramayana and Mahabharata stories. It is in these scenes that the puppeteer speaks out his messages to the audience through jokes among the clowns. In week 12, we will discuss the traditional performance and in week 13 modern performance. The discussion of this topic will include the structure of the performance and the differences between them.

The third category, shadow puppets and social and cultural issues, examines the relations between shadow puppets and Javanese culture in general. In week 3, as I have mentioned above, we will discuss shadow puppets and The Year of Living Dangerously. In week 9 we will discuss shadow puppets and education. Through the dialogues between characters, the puppeteer educates the audience in many aspects of lives, ranging from mystical, ethical, aesthetical, social to political education (Hadisoeseno, 1955). Specific messages are usually spoken out during the clown servant scenes. In week 10, we discuss the relations between shadow puppet performances and Javanes ritual celebrations. The celebration of life cycles, such as birth, circumcision, and wedding are usually accompanied by shadow puppet performances; even death is celebrated with a shadow puppet performance (Keeler, 1992). We will also discuss shadow puppet performances in other rites such as Independence Day and village ritual celebrations.

In week 11, the topic is shadow puppet and propaganda. The discussion will include how the New Order regime (1966-1998) manipulated shadow puppet performances to maintain power. Soeharto took over the power from Soekarno in 1966 after the rebellion of the Indonesian Communist Party (PKI) failed to take over the power in Indonesia. As soon as Soeharto was in power, he banned the PKI and punished those who involved in the rebellion. For more than thirty years in power, Soeharto did everything to maintain his power, including using shadow puppet performances as a means of propaganda. The role of clown servants, especially Semar, is very crucial in this case. Even Soeharto once identified himself as Semar, a clown servant who is actually a god (Pausacker, 2004). 


\section{THE READINGS}

Brandon's (1970) On Thrones of Gold: Three Javanese Shadow Plays, Keeler's (1987) Javanese Shadow Plays, Javanese Selves, and also Keeler's (1992) Javanese Shadow Puppets would be important readings for the course. The book by Brandon is a classic in Javanese shadow puppets. He translated three plays (or lakon in Javanese) from Javanese into English. He also discussed the dramatic structure of the shadow puppet performance and other key components of the performance. Reading this book, non-Javanese and nonIndonesian readers will be able to enjoy three complete Javanese shadow plays. Meanwhile, the two books by Keeler are anthropological studies of Javanese shadow puppets. Keeler analyzes aspects of Javanese society and culture through the shadow puppets. The three books are seminal works on Javanese shadow puppets. Another book by Brandon (1967) I use for this course is Theatre in Southeast Asia. This book is important in the discussion of the cultural setting of shadow puppets across Southeast Asian countries. In particular, I use this book for the discussion of the history of Javanese shadow puppets which received their influence(s) from Hindu, Buddhist, Islamic, and also Western traditions. However, I do not require students to read the three books in their entirety but only chapters or parts that are really related to the topics.

Because the Ramayana and the Mahabharata are the basis of Javanese shadow puppet stories, I use the two books as requirements. I chose the Ramayana version by R.K. Narayan (2000) and the Mahabharata version also by R.K. Narayan (2006) for at least two reasons: (1) the version is the most concise I have found so far, and (2) the version is written in modern English so it will be an easy read. By reading the shortened version of the epics, students will be able to understand the basic stories. After reading these two books, if they are interested in understanding more about the epics, they can read other versions. For the additional reading materials of the stories, I chose Valmiki's (1988) The Concise Ramayana and William Buck's (1973) Mahabharata.

Other books that I chose are Clara van Groenendael's (1985) The Dalang Behind the Wayang: The Role of the Surakarta and the Yogyakarta Dalang in Indonesian-Javanese Society; Hadisoeseno's (1955) Wayang and Education; Koch's (1995) The Year of Living Dangerously (a novel); Long's (1982) Javanese Shadow Theatre: Movement and Characterization in Ngayogyakarta Wayang Kulit; and Blackham's Shadow Puppets. Of these books, it is only Hadisoeseno's that I want students to read in its entirety. This is a very short book of only 
eighteen pages and exclusively discusses the relation between wayang and education. He discusses how shadow puppets can be used to teach the mystical, ethical, aesthetical, social and political education. From Clara van Groenendael's, I want students to read "Appendix II" only, "Structure of a wayang play in the Surakarta tradition." I need to emphasize here that there are two traditions in shadow puppet plays, i.e. Surakarta and Yogyakarta. Both are kingdoms in Central Java and in many respects, each of them differs slightly, including in shadow puppet performances. Reading this part of the book, together with Long's (1982), Keeler's (1992) and Brandon's (1970), students can make comparisons between the structure of shadow puppet performances in Surakarta and Yogyakarta. Meanwhile, Chapter I of Long's book is important for introducing Indonesian shadow puppetstogether with a chapter from Keeler, and Blackham. However, a chapter from Blackham is more comprehensive.

There is no single book that discusses one topic only. Some of the books I chose can be used for the discussion of many topics, such as Keeler (1992) and Brandon (1970). In contrast, I chose certain parts of some books for discussing certain topics. I designed the course syllabus in such a way so that students will be able to know quickly what books to read for certain topics in certain weeks or which chapter or part of a book to read for certain topics in a certain week. Koch's (1995) The Year of Living Dangerously is also an important book in this course. The setting of the novel is set in Jakarta (Indonesia) in 1965, when Indonesia was under Soekarno, the first president. Reading this novel, students will gain important social and cultural background information about Indonesia. Koch discusses the political conflicts in Indonesia between the military and the Indonesian Communist Party (PKI) which he describes as constant conflicts like the ones between the Pandawa and Kurawa.

In Indonesian shadow puppets, the constant conflicts between the Pandawa and Kurawa are solved in the ultimate war, Baratayuda, in which all of one hundred Kurawa brothers die. Koch constructed the novel like the dramatic structure of a shadow puppet performance: part one (pathet nem), part two (pathet sanga), and part three (pathet manyura) (Brandon, 1970). Koch also discusses some major shadow puppet characters in this novel. Reading this novel (along with watching its film version with the same title, released in 1982 starring Mel Gibson and Sigourney Weaver), students will be introduced to shadow puppets in some ways. Therefore, I devote one session to discussing this novel. 
In addition to the books, I also use journal articles written by many scholars interested in Indonesian shadow puppets. All required articles, except one, are written by foreign scholars who not only know well about shadow puppet stories but who also have watched shadow puppet performances many times. Sears (1989), Mrazek (1999; 2000) and Cohen (2007) tell us that they watch hundreds of shadow puppet performances during their stay in Java. There is no doubt that their knowledge and understanding about shadow puppets are 'valid.' Even Cohen himself is a puppeteer. Reading the articles, American and international students will gain "first hand" information about shadow puppets from the foreigner's point of view. I chose most articles by foreign scholars because I want to introduce students to those scholars who really love shadow puppets (to some degree, I could say that they love shadow puppets more than common Javanese do). By choosing their writings, as a Javanese I want to appreciate what they have done to disseminate shadow puppets in particular and Javanese culture in general to the international public. No doubt that from the scholarly perspective, what they have done deserves more than just an appreciation. Their writings are valuable sources of Javanese shadow puppets and culture.

Campbell (1994) and Habel (2007) are helpful in understanding how Koch uses puppets as an important element in his novel. Reading these two articles will allow students to more easily understand the novel because they provide important information about social and cultural background. The additional reading for this topic is MacBean (1984). While Campbell and Habel discuss the novel, MacBean discusses the film. These pieces will be useful for students to compare the novel and the film.

Brown (2004), gives emphasis to what Hadisoeseno (1955) analyzes in his book that shadow puppet can be used as a way to teach ethics or moral values. In particular she suggests that teachers of kindergarten through second grade use a short version of shadow puppet stories to teach character education traits. Shadow puppets which are particularly Indonesian can be used to teach character education traits in American schools. This article will give very valuable information for those who want to become teachers.

For the topic of "Shadow Puppet and Javanese Rites," I chose two pieces by Hatley, "Wayang and Ludruk: Polarities in Java" (1971) as the additional reading and "National Ritual, Neighborhood Performance: Celebrating Tujuhbelasan" (1982) as the required reading. The first article has a broad scope, discussing the relation between shadow puppets and many 
aspects of Indonesian lives, including the traditional religious rituals. The second focuses on how shadow puppet performances are used "to mark the new, largely secular rituals of Indonesian life-state occasions, such as Independence Day, as well as local community events, such as the anniversary of the badminton club, youth group, etc" (p. 56). These two pieces, together with a chapter from Keeler (1992) show the importance of shadow puppet performances in ritual celebration in Indonesian culture.

Basuki (2006), Buruma (1984), and Clark (2001) are required pieces for the discussion of "Shadow Puppets and Propaganda." For the additional reading, I chose Pausacker (1984). In particular Basuki focuses on how the New Order regime under Soeharto (1966-1998) manipulated shadow puppets to promote Soeharto as Semar, a wise, god-like character. He also analyzes the parallel between feudalism in shadow puppets and feudalism in the New Order regime. Likewise, Buruma analyzes the similar theme in his short piece. He emphasizes how shadow puppets are identical with Javanese lives and therefore are easy to use as a political propaganda. Clark (2001) analyzes Indonesian literature during the New Order regime. He found that many writers rewrote the Ramayana stories in their novels, short stories and plays and poetry. The writings are a kind of critique of the regime. Soeharto, the president for more than thirty years, were seen by many Indonesian artists as a king like in shadow puppet stories. He repressed critical performing artists and writers. Together with Basuki and Buruma, Clark will provide good ideas and resources for the class discussion. The additional reading for this topic is Pausacker (2004). She analyzes how the New Order regime manipulates shadow puppet to strengthen its power by creating an image that the president (Soeharto) functioned as the servant for his people (just like punakawan or clown servants to their master). He liked to be portrayed as Semar. Pausacker also discusses how Indonesian presidents after Soeharto, Habibie and Abdurachman Wahid, were portrayed as Gareng and Bagong (both are Semar's sons).

For the topic of "Modern Performance: The Changing Nature of Shadow Puppet Performance," Sears (1989) is a good read. She discusses the development of shadow puppet performances from traditional to modern. This article is important in looking at how shadow puppet performances have been changing from traditional to modern. In the discussion of the modern performance, Sears focuses on padat (compressed) performances which could only last for about one to one and a half hour. In this article we gain much information about what factors cause the changes. The additional reading is Margono-Slamet (2003) in which he focuses on the cultural 
debates around the shadow puppet performances between the traditionalists and modernists.

For the discussion of "Shadow Puppets in Global Context: New Directions and Techniques," the required reading is Cohen (2007). His article lays out how shadow puppets develop from an Indonesian traditional performing art to a modern performing art which spreads globally. A puppeteer himself, he has a pivotal role in spreading shadow puppet theatre internationally (Indonesian performance, n.d.). Reading this, students will have much information about the place of Indonesian shadow puppets in international communities. The additional readings for this topic are Mrazek (1999, 2000). These two pieces are very informative in terms of the contemporary shadow puppet performances. Mrazek discusses many issues such as how modern western music comes to shadow puppet performances, how audience and the puppeteers communicate directly and freely in a performance, and how the puppeteers have more freedom in addressing social issues in their performances.

Two other additional readings are de Bruin and Brakel-Papenyzen's (1992) "The Death of Karna: Two Sides of a Story" and Poplawska's (2004) "'Wayang Wahyu' as an Example of Ehristian Forms of Shadow Theatre." de Bruin and Brakel-Papenyzen compare two stories of the death of Karna, one is a Tamil story and the other is a Javanese. They analyze whether one influences the other. I chose this article for the topic of "Some Shadow Puppet Stories." Meanwhile, I chose Poplawska (2004) for the topic of "Shadow Puppets and Education." She focuses on how the Indonesian Catholics create a new kind of shadow puppet, Wayang Wahyu, to attract new believers. The characters and stories in Wayang Wahyu are taken from the Bible stories. Together with Hadisoeseno (1955) this article will give students important information about the relation between shadow puppet and education, including religious education.

\section{THE VIDEOS}

I attempted to balance between the videos of the Ramayana and Mahabharata stories and between the traditional and the modern performances and decided to choose short videos (the longest video, "Indonesia: The Ultimate in Diversity," lasts for about eleven minutes), except the film version of The Year of Living Dangerously, which I will play completely in class. This way, the videos will not take too much time of the 
class. Some videos will be played in the beginning of the class. Students can watch them first at any time because I provide the links of all videos. The additional videos and the videos to consider for the final paper will not be played in class.

All videos, except the film, are extracts from performances of certain plays, or lakon. For non-Javanese, this makes it difficult to tell the differences; unless the language is in English. I do a lot of research to find videos in English. I am lucky because I find some videos in English, including performances by Cohen. For the videos in Javanese, I need to explain them to students (whenever possible I will provide some translations) so that students can make the most of them.

\section{CONCLUSION}

There are two levels of potential outcomes for students in this course. At the basic level, my expectation is that students will have general understanding of the major topics such as shadow puppet characters and stories, shadow puppet performances, and shadow puppets and social and cultural issues. Regarding the shadow puppet characters, I expect that at the end of the course students understand the major characters from both the Ramayana and Mahabharata and their role in the stories. In particular, I expect them to know at least one character very well. I also expect them to know some stories of shadow puppets, both from the Ramayana and Mahabharata. In regard of shadow puppet performances, I expect that students will know the key components of the performance and the differences between traditional and contemporary performances. In terms of shadow puppets and social and cultural issues, I expect that students know how shadow puppets play significant roles in ritual celebrations, education, propaganda, and also know the place of shadow puppets in global context. At the deeper level, I expect that students will have broader visions and perspectives about other cultures. In this course, my expectation is that through shadow puppets, students will know better about Indonesian cultural values. For those who later want to work in educational field or become teachers especially, I expect that they can use shadow puppets as a way to teach their students about other cultures.

In essence, as I have mentioned above, I expect that this coursethrough the readings, videos, assignments, and discussions-can help students become global citizens by understanding other cultures. As an 
expectation, this may sound too big; but this course can become a good start to achieve the goal because by offering materials in another culture, this course also offers new possibilities that students can explore.

\section{REFERENCES}

Anderson, B.R. O'G. (1991). Imagined communities: Reflections on the origin and spread of nationalism. London: Verso.

Anderson, B.R. O'G. (1996). Mythology and the tolerance of the Javanese. Ithaca: Cornell Modern Indonesia Project, Southeast Asia Program, Cornell University.

Basuki, R. (2006). Panakawan's discourse of power in Javanese shadow puppet during the New Order regime: From traditional perspective to new historicism. Kata, 8(1), pp. 68-88.

Blackham, O. (1979). Shadow puppets. London: Barrie and Rockliff.

Brandon, J.R. (1967). Theatre in Southeast Asia. Cambridge, Mass.: Harvard University Press.

Brandon, J.R. (1970). On thrones of gold; three Javanese shadow plays. Cambridge: Harvard University Press.

Brown, S. (2004). Building character through shadow puppetry. Art Education, 57(6), pp. 47-52.

Buck, W. (1973). Mahabharata. Berkeley: University of California Press.

Buruma, I. (1984, August 9). Political propaganda and the power of the puppets. Far Eastern Economic Review, pp. 35-36.

Campbell, F. (1994). Silver screen, shadow play: The tradition of wayang kulit in The Year of Living Dangerously. The Journal of Popular Culture, 28 (1), pp. 163-169.

Cohen, M.I. (2007). Contemporary wayang in global context. Asian Theatre Journal, 24(2), pp. 338-369. 
Clara van Groenendael, V.M. (1985). The dalang behind the wayang: The role of the Surakarta and the Yogyakarta dalang in Indonesian-Javanese society. Dordrecht, The Netherlands: Foris.

Clark, M. (2001). Shadow boxing: Indonesian writers and the Ramayana in the New Order. Indonesia, 72, pp. 159-187.

Cushner, K. \& Brennan, S. (2007). The value of learning to teach in another culture. In K. Cushner and S. Brennan (Eds.), Intercultural student teaching: A bridge to global competence. Lanham, MD.: Rowman \& Little field Education, pp. 1-11

de Bruin, H.M. and Brakel-Papenyzen, C. (1992). The death of Karna: Two sides of a story. Asian Theatre Journal, 9 (1), pp. 38-70.

Fadiman, A. (1998). The spirit catches you and you fall down: A Hmong child, her American doctors, and the collision of two cultures. New York: Farrar, Straus, and Giroux.

Habel, C. (2007). Shadow on screen: The wayang kulit in the Year of Living Dangerously. Journal of the Association for the Study of Australian Literature, 7, pp. 46-58.

Hadisoeseno. (1955). Wayang and education. Djakarta: Ministry of Education and Culture of the Republic of Indonesia.

Hatley, B. (1971). Wayang and Ludruk: Polarities in Java. The Drama Review, 15 (2), pp. 88-101.

Hatley, B. (1982). National ritual, neighborhood performance: Celebrating tujuh belasan. Indonesia, 34, pp. 55-64.

Holland, D., Lachicotte, W., Skinner, D., Cain, C. (2003). Identity and agency in cultural worlds. Cambridge: Harvard University Press.

Indonesian performance. (n.d.). Retrieved on February 23, 2011 from http: //indonesian performance.blogspot.com/

Iyer, A. (2001). Introduction: Performing arts of Indonesia: Tradition, continuity, change and the transition to the West. Contemporary Theatre Review, 11 (1), pp. 1-8. 
Keeler, W. (1987). Javanese shadow plays, Javanese selves. Princeton, NJ: Princeton University Press.

Keeler, W. (1992). Javanese shadow puppets. New York: Oxford University Press.

Koch, C. J. (1995). The Year of Living Dangerously. New York: Penguin Books.

Long, R. (1982). Javanese shadow theatre: Movement and characterization in Ngayogyakarta wayang kulit. Ann Arbor, Michigan: UMI Research Press.

MacBean, J. R. (1984). Watching the third world watchers: The visual, the verbal, the personal and the political in "Under Fire" and "The Year of Living Dangerously.” Film Quarterly, 37(3), pp. 1-13.

Margono Slamet, Y. B. (2003). Contemporary wayang kulit performance: A crisis in Javanese culture? Culture, English Language Teaching $\mathbb{E}$ Literature, 3(2), pp. 144-158.

Mrazek, J. (1999). Javanese wayang kulit in the times of comedy: Clown scenes, innovation, and the performance's being the present world. Part One. Indonesia, 68, pp. 38-128.

Mrazek, J. (2000). Javanese wayang kulit in the times of comedy: Clown scenes, Innovation, and the performance's being the present world. Part Two. Indonesia, 69, pp. 107-172.

Narayan, R. K. (2000). The Mahabharata: A shortened modern prose version of the Indian epic. Chicago: The University of Chicago Press.

Narayan R. K. (2006). The Ramayana: A shortened modern prose version of the Indian epics. New York: The Penguin Group, Inc.

Orr, I. C. (1974). Puppet theatre in Asia. Asian Folklore Studies, 33 (1), pp. 69 84.

Pausacker, H. (2004). Presidents as punakawan: Portrayal of national leaders as clown-servants in Central Javanese wayang. Journal of Southeast Asian Studies, 35 (2), pp. 213-233.

Poplawska, M. (2004). "Wayang Wahyu" as an example of Christian forms of shadow theatre. Asian Theatre Journal, 21 (2), pp. 194-202. 
Pustaka Raja Purwa. (n.d.). In Wikipedia. The Free Encyclopedia. Retrieved on February 23, 2011, from http://id.wikipedia.org/wiki/Pustaka_ Raja_Purwa

Sears, L. L. (1989). Aesthetic displacement in Javanese shadow theatre: Three contemporary performance styles. TDR, 33(3), pp. 122-140.

The University of Iowa (n.d.). The Department of Asian and Slavic Languages and Literatures. Retrieved on February 20, 2011 from http://www .uiowa.edu/ ${ }^{\sim}$ asll/.

The University of Iowa. (n.d.). South Asian Studies Program. Retrieved on February 20, 2011 from (http://international.uiowa.edu/centers/ sasp/).

Valmiki. (1988). The concise Ramayana. Albany: State University of New York Press.

Wright, Lorna. (1994). Indonesia: Myth and reality in the land of the shadow puppet. International Studies of Management \& Organization, 24 $(1 / 2)$, pp. $35-60$.

\section{The Videos}

"Anoman's victory" by Matthew Isaac Cohen, http://www.youtube.com/ watch? $\mathrm{v}=4 \mathrm{DBb} 5 \mathrm{~g}-9 \mathrm{~B} 9 \mathrm{~A}$

"Antareja Rangsang” ("Antareja rebels") by Ki Hadi Sugito, http://www.youtube.com/watch?v=VJgxc249RZQ\& feature=related

Balinese puppets (Video: "Balinese shadow puppet Part I," http://www. youtube.com/watch?v=7XZTn3H1WnY)

"Brontoyuda Jayabinangun" ("The Baratayuda War"), http://www. youtube.com/watch? ${ }^{=}=$BmeskwievQs

Cambodian shadow puppet play, "Sbek Thom, Khmer Shadow Theatre," http://www.youtube.com/watch? v=jkwlplUOW4g

"Cangikan wayang kulit Ki Joko Edan, Gogon \& Diqin" ("Cangikan by The Crazy Joko, Gogon \& Diqin") http://www.youtube.com/watch? $\mathrm{v}=$ YivCRSVwCIA 
Slamet, Y.B.M., Constructing a Course on Indonesian Shadow Puppets for

"Clowns from a wayang performance," http://www.youtube.com/watch?v=

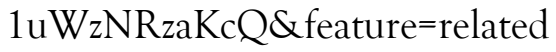

“Empat wayang Ki Enthus \& Thukul Arwana” ("Ki Enthus's four puppets \&

Thukul Arwana"), http://www.youtube.com/watch?v=-CnZgr4k1Cc $\&$ feature $=$ related

"Goro-goro" ("Clown servant scene"), http://www.youtube.com/watch?v= g7xlon7v5WY

"Indonesia: The ultimate in diversity", http://www.youtube.com/watch? $\mathrm{v}=\operatorname{tpdF} 7 \mathrm{mH} 36 \mathrm{mM}$

Indonesian shadow puppet play, "Wayang kulit: shadow theatre in Java Part 1," http://www.youtube.com/watch?v=dypiAo5wN6s\& feature= related

"Indonesian shadow puppet show," http://www.youtube.com/watch?v=6fVx PoRu2bw\&NR=1

Javanese puppets (Video: "Javanese shadow puppets: Wayang kulit Jawa, Mahabharata Scene," http://www.youtube.com/watch?v=RS9LROKM L9c\& playnext $=1 \&$ list $=$ PL 57FD32D28EC 50317\& index $=56$

"Ki Enthus goro-goro dalang edan," ("Goro-goro by Ki Enthus, the crazy puppeteer) http://www. youtube.com/watch?v=QAqWnt2U5-Y

"Ki Enthus Topeng Monyet \& Thukul Arwana" ("Mask of Ape by Ki Enthus \& Thukul Arwana"), http://www.youtube.com/watch?v=FSEWcHdM WQo\&feature=related

"Ki Purbo Asmoro, Brubuh Alengka" ("The fall of Alengka)," http://www. youtube.com/ watch?v=LJP4Lu_aO8c\&feature=related

"Mahabharata scene: Arjuna slays a giant," http://www.youtube.com/ watch?v=Of7ViIM9Wwc

Malaysian shadow puppet play, "Wayang kulit Saupi," http://www .youtube.com/ watch?v=KM1du_obkp8\& feature=related

"Pada sebuah ranjang by Sujiwo Tejo" ("In bed by Sujiwo Tejo") http://www.you tube.com/watch?v=c3aXfKypG2o

"Ramayana shadow puppet," http://www.youtube.com/watch?v=ReriYz4Q seQ\& feature=related 
"Sarpakenaka" (From The Abuction of Sinta) by Matthew Isaac Cohen, http://www. youtube.com/watch? $=$ LXc7Ze00YLI

"Slamet Gundono dan komunitas wayang suket, 1" ("Slamet Gundono and the community of grass puppets, 1") http://www.youtube.com /watch?v=Zu6t1JqU-WI

"Some demons from a wayang performance," http://www.youtube.com/ watch? $v=P b K f w o 951 \_w \&$ feature=related

Sundanese puppets (Video: "Wayang Golek, puppeteers of West Java Part I," http://www. youtube.com/watch?v=1_0om5q18AA)

Thai shadow puppet play, "University of Michigan - Thai night 2008: Shadow puppet," http://www.youtube.com/watch?v=VI7iQkM ZJ-o

"The fall of Alengka" by Matthew Isaac Cohen, http://www.youtube. $\mathrm{com} /$ watch? $=$ Qx6Nb6orcHA

"The Magical Lake" by Matthew Isaac Cohen, http://www.youtube.com/ watch?v=JVUvUiLItdg\&NR $=$

"The tournament" by Matthew Isaac Cohen, http://www.youtube. com/watch? $\mathrm{v}=$-Sh8zsZxeG4 The Year of Living Dangerously. (1982). Director P. Weir; screenplay by C.J. Koch, P. Weir, D. Williamson. MGM/United Artists.

"Wayang kulit - Bu Harni (Mrs. Harni) - Man vs. Horse, Man vs. Bike,"http://www.youtube.com/watch? $=$ =paxXt7iSvkc\& playnext $=1 \&$ list=PL8DFB9F6024499 A77

"Wayang kulit 'goro-goro' Ki Anom Suroto" ("Clown servant scene” by Ki Anom Suroto)http://www.youtube.com/watch?v=FiXMPm__ Lak

"Wayang kulit goro-goro Ki Anom Suroto" ("Clown scene by Ki Anom Suroto"), http://www.youtube.com/results?search_query=gorogoro $+\mathrm{ki}+$ anom + suroto\&aq $=0$

(Note to the videos: There are eleven parts of this video. To watch them all, just click the videos one after another).

"Wayang performance of Ciptoning," http://www.youtube.com/watch ?v=SiThcOwbP_0 
Slamet, Y.B.M., Constructing a Course on Indonesian Shadow Puppets for

"Wayang kulit: Purbo Asmoro (Profile in English)," http://www. youtube.com/watch? $\mathrm{v}=$ brT6A71Cz $1 \mathrm{c} \& \mathrm{NR}=1$

"Wayang kulit: Shadow theatre in Java. Part 2,"http://www.youtube.com/ watch? $=\mathrm{C} 9$ oa0 G6TcOc\& feature=related

"Wayang kulit: Shadow theatre in Java. Part 3," http://www.youtube.com/ watch? $=\leadsto \mathrm{rO} \mathrm{mYTjdlc} \&$ feature $=$ related

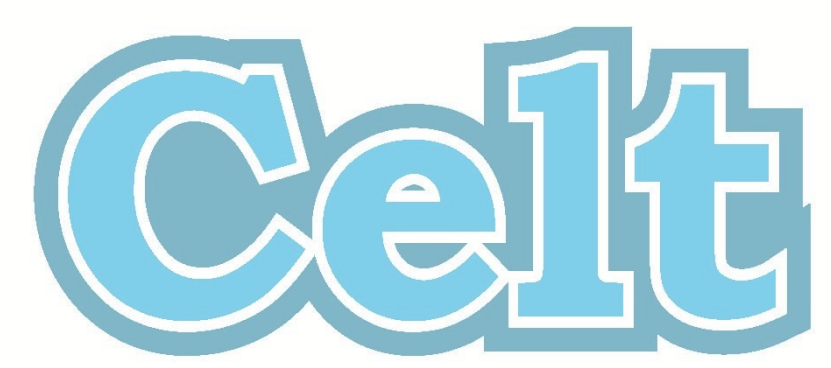

